\title{
INTENSIFICATION OF EDUCATIONAL INTERACTION IN DISTANCE LEARNING FORMAT AT HIGHER EDUCATION ESTABLISHMENTS
}

\author{
ІНТЕНСИФІКАЦІЯ ПЕДАГОГІЧНОЇ ВЗАЄМОДІЇ В УМОВАХ \\ ДИСТАНЦІЙНОГО НАВЧАННЯ В ЗАКЛАДАХ ВИЩОЇ ОСВІТИ
}

\begin{abstract}
The article is devoted to the topical problem of distance learning at higher education establishments. Based on the analysis of scientific and pedagogical literature, the approaches of scientists to the concepts of "distance education", "distance learning", "educational interaction" are highlighted. The definition of the concept "intensification of educational interaction in the distance learning format" is given. It has been found out that cyclical, dialogical, constructive interaction aimed at joint productive activity of its participants causes intensification of educational interaction in higher education establishments. The basic principles of the organization of educational interaction are covered: the principle of dialogical interaction, the principle of problematization of the content of training, the principle of student-centeredness. Features of the organization of educational interaction in distance learning format are characterized. It has been determined that the complexity of the organization of educational interaction in distance education lies in creating a special communicative field of the educational process; the effectiveness of the communicative field depends on the ways of combining its parameters: the number of participants in the interaction and the distance between them; density of information exchange; technical means. The basic principles of intensification of educational interaction in higher education establishments are given: motivation for interaction between student and teacher, student and student(s); mutual exchange and cooperation between the agents of interaction; interactive learning technologies; prompt feedback; the time required to complete the task; informing students about learning outcomes; use of various teaching methods and tools, technical means. Three types of interaction in distance learning format are considered: "student - content", "student - teacher", "student - student(s)". Methods of intensification of educational interaction in distance education are given, the expediency of their application is substantiated.

Key words: distance learning, higher education establishment, educational interaction, didactic interaction, intensification of educational interaction in distance learning format.
\end{abstract}

Статтю присвячено актуальній проблемі інтенсифрікації педагогічної взаємодії у фор- маті дистанційного навчання в закладах вищої освіти. На основі аналізу науковопедагогічної літератури висвітлено підходи науковців до понять «дистанційна освіта», «дистанційне навчання», «педагогічна взаємодія». Надано визначення поняття «інтенсисрікація педагогічної взаємодії в умовах дистанційного навчання». З'ясовано, що циклічна, діалогічна, конструктивна взаємодія, що спрямована на спільну продуктивну діяльність ї̈ учасників, зумовлює інтенсифрікацію педагогічної взаємодії в закладах вищої освіти. Висвітлено основні принципи організації педагогічної взаємодії: принцип діалогізації, принцип проблематизації змісту навчання, принцип студентоцентрованості. Охарактеризовано особливості організації педагогічної взаємодії в умовах дистанційного навчання. З'ясовано, що складність організації педагогічної взаємодії в дистанційній освіті полягає у створенні особливого комунікативного поля освітнього процесу; ефективність комунікативного поля залежить від способів поєднання його параметрів, як-от: кількість учасників взаємодії та відстань між ними; щільність взаємообміну інфрормацією; технічні засоби. Наведено основні принципи інтенсисрікацій педагогічної взаємодії в закладах вищо освіти: умотивованість до взаємодії між студентом і викладачем, студентом та студентом(ами); взаємообмін і співпрацю між суб'єктами взаємодіі;; інтерактивні технології навчання; оперативний зворотний зв'язок; час, необхідний для виконання завдання; інфоормування студентів щодо результатів навчання; використання різ них методів та засобів навчання, технічних зокрема. Розглянуто три типи взаємодіі в умовах дистанційного навчання: «студент - контент», «студент - викладач», «студент -студент(и)». Наведено методи інтенсифрікації педагогічної взаємодії в дистанційній освіті, обгрунтовано доцільність їх застосування.

Ключові слова: дистанційне навчання, вищий навчальний заклад, педагогічна взаємодія, дидактична взаємодія, інтенсифрікація педагогічної взаємодії в умовах дистанційного навчання.
Introduction. The COVID-19 pandemic has forced most of the world's educational systems to switch to a distance learning format (hereinafter-DL). Since March 2020, many countries, including Ukraine, have been a subject to severe isolation measures associated with nationwide lockdowns. Despite the fact that higher educational institutions (hereinafter - HEIs) have significant theoretical and practical experience in implementing distance learning, adaptation to changing requirements in the short term has become a challenge for HEls, which should ensure the continuity of educational services and their quality. The quality of DL depends on various factors, including the availability and technical equipment of DL learning platforms, quality of the Internet-communication, access to distance learning technologies, interaction of students and teachers, etc.

The interaction between the participants of the educational process that determines satisfaction as well as a positive attitude to learning and, consequently, higher learning outcomes has become a crucial factor for the effectiveness of DL. Meanwhile, the rapid transformation of educational activities has led to the "copying" of traditional organizational forms of learning 
and assessment methods in the format of DL resulted in a lack of interaction, educational one in particular, between participants of the educational process.

Analysis of recent research and publications. Theoretical and practical aspects of distance learning were considered in the works of both foreign and domestic scientists: O. Andreev, V. Bykov, V. Kukharenko, E. Polat, O. Rybalko and others. The issues of using the innovative computer technologies in were studied by I. Bogdanova, T. Koval, S. Konyushenko, M. Zhaldak and others.

The conducted theoretical analysis also showed that the problem of interaction was investigated by domestic and foreign scientists in the following fields of research: philosophical and cultural aspect (O. Jesuitov, S. Karepova, M. Kagan, G. Bush and others); various aspects of educational interaction (O. Bodalov, V. Kan-Kalyk, O. Leontiev, I. Zimnya, Y. Babanskyi, V. Slastyonin, O. Gonchar and others). However, it should be noted that the intensification of the educational interaction in the educational process at HEls as a pedagogical problem has not yet been examined with the in-depth analysis.

The aim of the article is to reveal the essence of the concept "intensification of educational interaction in higher educational institutions in the distance learning format", to characterize the features of educational interaction in the DL format, to determine the basic principles of educational interaction intensification in the DL format.

Methods: analysis, comparison, generalization and systematization of scientific and theoretical principles, synthesis.

Literature review and discussions. The concept of distance learning has different interpretations as a scientific and educational problem due to the different level of research of distance education (hereinafter - DE). Based on the review and qualitative analysis of the scientific and educational literature, scientists O. Zawacki-Ritzgter, E. Batsker and S. Vogt identified three meta-levels that highlight the current research fields and underpin the understanding of the concept "distance learning" by scholars: 1) macro level: systems and theories DE (access to $D E$, equality in access to DE, ethical issues, globalization of education and cross-cultural issues, systems and institutions of DE, theories and models of $D E$, research methods in DE and knowledge transfer); 2) meso-level: management of DE, organization and technologies of DE (economic issues, DE efficiency, educational technologies, innovations, technical support services for those who study in the DE format, quality assurance of DE); 3) micro level: teaching and learning in distance education (DE system design, interaction and communication in DE, characteristics of participants) [1].

In our research, we focus on the micro level of research and consider $\mathrm{DL}$ as a form of $\mathrm{DE}$, which has the following characteristics: is an electronic form of organized educational process (V. Bykov, O. Fedorova); adapts traditional forms of classes and paper teaching aids to telecommunication, which determines the use of information and communication technologies (A. Rybalko, V. Kukharenko); has specific tools, modes, teaching methods ( $E$. Polat, A. Petrov); based on the principles of personalized learning (V. Yarovenko); provides interactive educational interaction of students and teachers without direct contact of participants of interaction (M. Moore); provides comprehensive support for purposeful and controlled intensive independent work of the listener (O. Pavlenko).

In this paper we rely on the concept of "distance learning", which is defined in the regulations of the Ministry of Education and Science of Ukraine as an individualized process of acquiring knowledge, skills, abilities and methods of human cognitive activity, which occurs mainly through indirect interaction process in a specialized environment that operates on the basis of combination of modern technologies (psychological-educational technologies as well as information and communication ones) [2].

The concept of "interaction" in the electronic environment, in DL in particular, scientists characterize as electronic communication (S. Nilova); computer communication or communication mediated by a computer (N. Volkova, O. Arestova); Internet communication (L. Khalyapin); computer-supported collaboration (O. Arestova); a human-computer interaction (N. Volkova).

It should be noted that in our work among the main types of communication via a computer, we define: the agent-object interaction, i.e. human-computer interaction; the agent-agent interaction, i.e. the interaction between the agents of the educational process carried out via a computer (computer-mediated interaction). In our study, we investigate the agent-agent interaction.

Educational interaction is interpreted by scientists as: educational communication (O. Bodalov, V. Kan-Kalyk and others) or communication as a mechanism of educational interaction (T. Yatsenko); a special kind of educational activity (K. Rogers and others); essential characteristics of the educational process (V. Slastyonin); a set of educational situations (I. Zyazyun, I. Krivonos, N. Tarasevich and others); way of organizing the educational process (Yu. Babanskyi); mutual activity and mutual influence of educational process participants (S. Smirnov, E. Shiyanov and others) [3].

In this work we define the intensification of educational interaction in the conditions of DL as an increase in the number of indirect situations of educational interaction aimed at solving problems of the educational process to enhance student learning outcomes. 
Scientists A. Chickering and Z. Gamson outlined the principles of providing quality educational services by HEls, which determine the intensification of educational interaction in the educational process, namely: encouraging interaction between student and teacher, student and student (s); mutual exchange and cooperation between the agents of interaction; interactive learning technologies; prompt feedback; the time required to complete the task; timely informing students about learning outcomes; the use of various teaching methods and techniques as well as ones supported with technical means in particular [4].

Significant qualitative parameters of educational interaction in the DL format affecting the quantitative characteristics of the mentioned phenomenon are the following: the physical presence of participants (agents of interaction); mutual activity and mutual influence of interaction participants; purposeful communicative activity of participants mediated by a computer with the Internet access stipulating the use of information and communication technologies; joint work of educational process participants.

According to the principle of dichotomy and the criterion of «degree of activity», scholars distribute the following models of interpersonal interaction: mono-agent (linear) models of interaction and polyagent (cyclic) personality-oriented model of interaction. Linear models of interaction commonly lead to socio-psychological alienation of its participants as they are destructive and conflicting ones by nature. The agent-agent model of interaction is a constructive and interactive one characterized by each participant's purposeful influence on the other participant to satisfy his/her interests.

The modes of work characteristic to DL, in which the educational interaction of the subjects of the educational process is realized, differ in the level of interactivity and the level of intensification of educational interaction. To examplife:

- synchronous mode takes place in real time using audio, video conferencing, such as Zoom, Microsoft Teams, Google Meet, Skype, etc. (online classes, lectures, seminars, etc.), when all participants of the educational process are simultaneously present in the web-based environment. This mode helps to increase the level of intensification of educational interaction as this type of interaction is characterized by intermediate feedback;

- asynchronous mode carried out with a delay in time via interactive educational platforms, such as Moodle, Google Classroom, or other means e-mail, forums, social networks, etc. The educational process is delivered according to a schedule convenient for teachers and students. Intensification of educational interaction is caused by timely messages, comments of interaction participants concerning the executed task, presentation and delivery of educational material, etc.
The agent-agent interaction, educational in particular, some scholars interpret as the communication process of exchanging semantic information, i.e. the transmission of symbols. Communicative activity consists of communicative actions, "consciously aimed at their semantic perception". The basis of communication is the interaction of people or interpersonal communication. The structure of communication includes: 1) at least two participants, endowed with consciousness, who are able to use the norms of a particular semiotic system (especially the language semiotic system); 2) the situation in which communication takes place and which the participants attempting to understand and comprehend; 3 ) texts, the linguistic means of which aimed at conveying the meaning of the situation; 4) motives and goals motivating the interation agents to communicate; 5) the direct process of transmission and perception of text messages in material form [5, p. 497]. The meaning of a verbal message is transmitted according to the scheme: recipient $\rightarrow$ message $\rightarrow$ encoding $\rightarrow$ channel $\rightarrow$ destination $\rightarrow$ decoding. The act of transmitting information from one person to another occurs in a communicative situation, which includes the communicator, his/her message, the recipient to whom it is addressed, the communication field, barriers and feedback. The process of encoding, transmitting and decoding the message takes place in the communicative field and is characterized by intensity. The communicative field in DE format is influenced by external conditions (availability and access to various e-learning materials, access to the Internet, the distance between participants, etc.), social norms (different from traditional education, design and delivery of practical classes, seminars, etc., assessment, and feedback communication, etc.), communication scripts (communicative situations of educational interaction mediated via a computer and means of information and communication technologies; therefore, educational interactions are significantly enriched with the didactic capabilities of all models of $\mathrm{DL}$ ).

The complexity of the educational interaction organization in the educational process communicative field in the DL format depends on the ways of combining its parameters. The parameters of the communicative field model defined by $\mathrm{O}$. Pinchuk include: the number of participants in the interaction and the distance between them: near (up to 8 people) and far (more than 8 people); density of mutual exchange of information - deep (use of all information resources available to participants of educational interaction) and superficial (partial or insufficient use of information resources); technical means (computer, tablet, etc.) direct (without the use of technical means) and indirect (with the support of technical means) [6].

Asynchronous DL is characterized by a near, superficial or deep, indirect model of the communicative field using interactive educational platforms (Moodle, 
Google Classroom, etc.). Far, deep, indirect model is typical for distance learning synchronous mode, which is widely used audio or video conferencing, such as Zoom, Microsoft Teams, Google Meet, Skype.

According to its structure, educational interaction corresponds to the structure of joint activities and consists of a preparatory stage (planning, modeling and organization of future activities), stage of management or co-management of students' learning activities through the creation of appropriate educational conditions, stage of evaluating the results of educational interaction.

Among the basic principles of educational interaction, scholars identify the following ones [7]:

- the principle of dialogization, i.e. for effective dialogic educational interaction the type of polyagent interaction is relevant characterized by equality of its participants, their readiness for cooperation and co-creation, coherence, productivity and effectiveness of cooperation, etc.;

- the principle of problematization of the content of education, which contributes to the acquisition of experience in heuristic and creative activities, the ability to make decisions, to form the participants' own style of activity, as well as development of personal qualities. In the DL format, this principle can be implemented through the creation of virtual communities, such as "Community of Inquiry", the use of thematic forums, chats and some more teaching methods;

- the principle of student-centeredness includes personalization and individualization of learning. Individualization of education in the DL format provides a flexible learning schedule due to its interactive nature supported with the use of information and communication technologies allowing the use of various technologies and teaching methods, such as "Flipped classroom" technology, gamification technology, "Peer teaching" technology, creating virtual communities, such as Community of Inquiry, using forums, chats, etc.

Personalization of education, in contrast to individualization, involves the creation of conditions for determining each student's own educational trajectory and is based on personality-oriented learning which changes the role of the teacher. The teacher is an assistant, facilitator of the student personality development. Due to this factor, the nature of the educational situation management changes - there is a gradual transition from management through co-management to self-management, the switch from the authoritarian character of interaction to democratic one. It changes the student's attitude to the acquisition of competencies from the reproductive acquisition of knowledge to a productive creative process initiated by the student in the process of joint activities and various forms of interaction. For example, students are invited to take a "Kahoot" quiz based on the study material, share additional information on the forum, comment, supplement and evaluate other students' messages ("Peer evaluation" technology), etc.

In M. Moore's work on interaction, three types of interaction have been identified: student-content, student-teacher, student-student(s) [8].

Student-content interaction. Scientists L. Velytchenko, O. Pinchuk define this type of interaction as a "didactic interaction". This type in essence is an interactive process of the system of educational tasks as well as the interaction between the student and the content of the discipline or the object of study [6]. The presentation of the content of the discipline and the formulation of educational tasks by the teacher are the determining conditions for the acquisition of knowledge, acquisition of skills and abilities by the student. This type of interaction should be aimed at internalization, i.e. the gradual formation of external activities into internal, consisting of three subsystems: subsystems of conditions ensuring the construction of a given action; subsystems of conditions supporting the acquisition of this action of the intended properties, qualities; subsystems of conditions of assimilation of an external action as a mental one. The intensification of student-content interaction depends on the nature of modeling of this educational interaction type by the teacher, as it can refer to information-oriented (or contemplative-reproductive) and interactive (or transformative-productive) interaction and affects learning outcomes.

The student-teacher interaction is focused on the dialogue between students and the teacher. It should be kept in mind that the task of a teacher in $D L$ is to design a communicative field, which involves the design of educational activities (content, operational and motivational activities), the design of educational influences and educational interaction organization mediated by a computer. The teacher should take into consideration the requirements to the dialogue, in particular the basic psychological requirements to maintain the appropriate level of students' motivation, taking into account the age and students' individual characteristics, as well as motives for using the Internet, the role of which increased significantly due to the COVID-19 pandemia, when HEls were forced to switch to the DL format.

The main motives for using the Internet include: business purposes, cognitive motives, communication; cooperation, self-affirmation, affiliation or group membership; self-realization, recreation and games. The predominant motives for using the Internet for students of HEls are cognitive motive, communication, affiliation.

According to M. Moore, the purpose of the student - teacher interaction is to intensify educational and cognitive activities by forming an indicative basis of activity, as well as positive students' motivation and self-motivation to study the discipline. N. Talizina notes that learners often underestimate the orienta- 
tion stage and "overjump" to the executive one, but at the initial, orientation stage, the students become aware of the purpose, plan and means of action and learn the scheme, algorithm of action, which is a system of guidelines and instructions for performing various actions [9]. To intensify the educational student teacher interaction teachers make presentations of the discipline, explains the discipline goals and objectives, outline the content, competencies, learning outcomes, diagnostic tools and the like. Teachers also provide counseling, and / or monitor and correct, if necessary, student learning activities. As N. Talizina states, operational control provides feedback and contains information on the compliance of a given educational activity independently performed by the participant of educational activity in an external form (for example, using models, diagrams, formulas, samples for simulation, drawings, etc.); monitor the correctness of activities, etc. Learning outcomes should be presented in the form of external language (oral or written). This provides a significant increase in the degree of generalization of action by replacing specific objects with their verbal description. Assimilation of educational activities is accompanied by an "internal didactic conversation", when learners tell to themselves the algorithm of the activity performance to be mastered. This type of interaction is characterized by intense feedback between the interaction participants. In DL, the interaction of students and teachers can be synchronous, mediated by video conferences, chats or asynchronous through correspondence, e-mail, and discussion boards.

Student-student interaction(s) take place in the teacher's physical presence in real time or at the specified time and have the following modes of educational activities organization - frontal mode (communication between one participant and the group), group mode (communication between two, three or more agents within the group among its members or with the teacher), pair mode (communication between two participants). According to the level of interpersonal relations formation, such educational interaction can be characterized as rivalry or cooperation. G. Siemens notes that the student - student (s)interaction in DL format can be considered as a four-stage continuum: 1. Communication: discussion of the problem and ways to solve it; 2 . Collaboration: exchange of ideas, information, resources, etc.; 3. Cooperation: each participant performs his part of the work and pursues his goal; 4. Community: combining the results of each work to achieve a common goal [10]. An example of a student-student interaction is the "Community of Inquiry" method. Therefore, for the intensification of the student - student interaction at HEls cooperation between the participants of the interaction is one of the crucial factors.

Conclusions. For the intensification of educational interaction in the DL format is accompanied with a cyclical, dialogical, constructive interaction aimed at joint productive activities of its participants. The complexity of the of educational interaction organization at HEls is explained through a special communicative field of the educational process, the effectiveness of which depends on combination of its parameters.

Further prospects in this direction are to substantiate the educational conditions for the intensification of educational interactions at HEls in the context of distance learning.

\section{REFERENCES:}

1. Zawacki-Richter O., Bäcker E., Vogt S. Review of Distance Education Research (2000 to 2008): Analysis of Research Areas, Methods, and Authorship Patterns. International Review of Research in Open and Distributed Learning. 2009. Vol. 10. № 6. P. 21-50. DOI: 10.19173/irrodl.v10i6.741.

2. Про затвердження Положення про дистанційне навчання : наказ МОН України від 25 квітня 2013 p. № 466. URL: http://zakon3.rada.gov.ua/laws/ show/z0703-13 (дата звернення: 16.04.2021)

3. Гончар О. Педагогічна взаємодія учасників навчального процесу в системі вищої освіти України (історико-педагогічний аспект) : монографрія. Харків : ХНАДУ, 2011. 432 с.

4. Chickering A., Gamson Z. Seven principles for good practice in undergraduate education. Biochemical Education. 1987. Vol. 17. № 3. P. 140-141. DOI: 10.1016/0307-4412(89)90094-0.

5. Новейший фрилософсский словарь / гл. научн. ред. А. Грицанов. 2-е изд., перераб. и доп. Минск : Интерпрессервис ; Книжный дом, 2001. 1280 с.

6. Пінчук О. Результати експериментальних досліджень застосування мультимедійних технологій в навчальному процесі базової школи. Проблеми освіти : науковий збірник / кол. авт. Київ : Інститут інноваційних технологій і змісту освіти МОН України, 2008. Вип. 55. С. 41-50.

7. Орлов А. Психология личности и сущности человека: парадигмы, проекции, практики. Москва : Логос, 1995. 224 c.

8. Moore M. Editorial: Three types of interaction. American Journal of Distance Education. 1989. Vol. 3. № 2. P. 1-7. DOI: 10.1080/08923648909526659.

9. Талызина Н. Педагогическая психология : учебное пособие для студентов средних педагогических учебных заведений. Москва : Издательский центр «Академия», 1998. 288 с.

10. Siemens R.G. Interaction. E-Learning Course. Computers and the Humanities. 2002. Vol. 36. № 3. P. 259-267. DOI: 10.1023/a:1016134426453. 